\title{
The Effect of Chitosan in Suppressing the Development of the Sheath Blight Disease (Rhizoctonia solani Khun) on Rice (Oryza sativa L.)
}

\author{
Okke Rosmaladewi $^{1 *}$, Muhammad Tandi ${ }^{1}$, Ummi Kulsum ${ }^{2}$ \\ ${ }^{1}$ Universitas Islam Nusantara, Bandung, 40286 \\ ${ }^{2}$ Balai Besar Peramalan Organisme Pengganggu Tanaman, Karawang, 41375 \\ *Corresponding author: okkerosmaladewi@uninus.ac.id MuhamadTandy96@gmail.com
}

Received January 06, 2020; revised February 12, 2020; accepted June 30, 2020

\begin{abstract}
Rhizoctonia solani is a fungal disease in rice plants that can cause damage to rice plants and reduce yield by $50 \%-80 \%$. This disease is difficult to control because it can survive in the soil for 2 years and spread easily. Efforts to control $R$. solani by using synthetic pesticides can couse negative impacts such as resistance, resurgence in plant pests. Therefore, alternative controls that are environmentally friendly and effective on target are needed. One of them is controling by using chitosan (extrct of shrimp shell waste) as a producer of antibiotics and amine (-NH2) functional groups. The purpose of this study is to obtain an effective concentration that can control and inhibit the development of Rhizoctonia solani both in vitro and in the field. The study was conducted in July 2018 - March 2019 at the Central Plant Pest Organisms Jatisari. The experiment used was a Randomized Block Design method with 8 treatments of chitosan concentration and 3 replications with a total of 24 plots. The results showed that powder of chitosan was able to supprese the growth of $R$ solani colony and reduce diseases intensity of $R$. solani. The best in vitro treatment to suprpress growth of $R$. solani that was the concentration of $1.5 \%$. This treatment inhibit mycelium growth by $77.37 \%$ and sclerotia by $81.13 \%$ while in the field experiment, it can inhibit the intensity of $R$. solani attacks by $9.67 \%$.
\end{abstract}

Keywords: Rhizoctonia, solani Khun, Chitosan, Inhibition

\author{
Abstrak \\ Pengaruh Kitosan Dalam Menekan Perkembangan Penyakit Hawar Pelepah (Rhizoctonia solani Khun.) pada \\ Tanaman Padi (Oryza sativa L.)
}

Rhizoctonia solani merupakan cendawan penyebab penyakit hawar pelepah pada tanaman padi yang dapat menyebabkan kerusakan pada tanaman padi dan menurunkan hasil hingga 50\%-80\%. Penyakit ini sulit dikendalikan karena dapat bertahan dalam tanah selama 2 tahun dan mudah menyebar. Upaya pengendalian cendawan $R$. solani dengan menggunakan pestisida sintetik dapat berdampak negatif seperti resistensi dan resurgensi pada organisme pengganggu tanaman. Oleh karena itu, diperlukan alternatif pengendalian yang ramah lingkungan serta tepat sasaran. Salah satunya yaitu pengendalian memanfaatkan kitosan (ekstrak limbah cangkang udang) sebagai penghasil antibiotik dan gugus fungsional amina $\left(-\mathrm{NH}_{2}\right)$. Tujuan penelitian ini adalah memperoleh konsentrasi yang efektif dalam mengendalikan dan menghambat perkembangan patogen R. solani baik secara in vitro maupun di lapangan. Penelitian dilaksanakan pada bulan Juli 2018 - Maret 2019 di Balai Besar Organisme Pengganggu Tumbuhan Jatisari. Percobaan disusun dalam Rancangan Acak Kelompok dengan 8 perlakuan konsentrasi kitosan dan 3 ulangan sehingga terdapat 24 unit/petak percobaan. Hasil penelitian menunjukkan bahwa perlakuan kitosan mampu menekan pertumbuhan koloni cendawan $R$. solani dan menekan perkembangan penyakit hawar pelepah. Penekanan terbaik terdapat pada perlakuan konsentrasi kitosan $1,5 \%$, secara in vitro mampu menghambat pertumbuhan miselium $R$. solani sebesar 77,73\% dan pembentukan sklerotia sebesar 81,13\%. Namun, hasil pengujian di pertanaman padi perlakuan kitosan hanya mampu menghambat intensitas serangan $R$. solani sebesar 9,67\%.

Kata Kunci: Rhizoctonia, solani Khun, Kitosan, Penghambatan

\section{PENDAHULUAN}

Seiring meningkatnya jumlah penduduk di Indonesia permintaan bahan pangan beras terus mengalami peningkatan dari tahun ke tahun. Kebutuhan akan penyediaan beras untuk tahun 20072017 mengalami peningkatan sebesar 0,67\% dan konsumsi rata-rata beras meningkat sebesar 124,89 kg per kapita per tahun (Dinas Pertanian Tanaman Pangan Jawa Barat, 2018). Dengan demikian untuk memenuhi konsumsi masyarakat maka harus diiringi dengan produktivitas padi yang tinggi. Namun, dalam kenyataannya produktivitas padi di Indonesia masih rendah. Menurut Badan Pusat Statistik (2018), produksi padi dari tahun 2014-2018 mengalami kenaikan mencapai $4,74 \%$ per tahun. Meskipun mengalami peningkatan selama produksi padi dari tahun ke tahun tetapi dalam skala produktivitas masih mengalami penurunan yang sebelumnya pada tahun 2016 sebesar 52, $36 \mathrm{Ku} / \mathrm{Ha}$ dan pada tahun 2018 menjadi 51,92 Ku/Ha. Penurunan produktivitas padi tersebut disebabkan oleh banyak faktor, diantaranya beberapa gangguan jenis Organisme Penganggu Tanaman (OPT) pada padi yang belum dapat diatasi dengan baik. Salah satu penyakit yang paling 
merugikan petani padi yaitu adanya penyakit hawar pelepah yang disebabkan oleh Rhizoctonia solani, yang dapat menurunkan produksi padi baik secara kualitatif maupun kuantitatif (Guo et al., 2006). Di Indonesia penyakit hawar pelepah yang disebabkan cendawan $R$. solani merupakan salah satu penyakit yang berkembang semakin parah dari musim ke musim terutama di daerah pertanian padi yang intensif. Penyakit ini berkembang dengan tingkat keparahan bervariasi dan diduga berkaitan erat dengan teknologi bercocok tanam yang diterapkan oleh petani, serta dipicu oleh kondisi lingkungan di sekitar tanaman yang lebih hangat dan lembab (Nuryanto, 2017).

Cendawan $R$. solani merupakan patogen tular tanah (soil borne pathogen) yang dapat bertahan dalam tanah dalam bentuk sklerotia, terutama pada tanah-tanah yang banyak mengandung pupuk anorganik dengan dosis tinggi nitrogen. Di beberapa sentra produksi padi, penyakit hawar pelepah menyebar merata, terutama jika ditanam pada musim hujan. Soenartiningsih et al. (2015), menyatakan bahwa gejala yang disebabkan oleh serangan $R$. solani seperti pada bibit tanaman padi menjadi sakit, layu dan akhirnya mati. Pada tanaman dewasa, penyakit hawar pelepah menunjukkan bercak besar yang tidak beraturan pada bagian pelepah yang disebut hawar (blight). Sehingga tanaman padi mudah rebah selanjutnya dalam keadaan parah dapat menyerang daun bendera yang menyebabkan kematian seluruh daun dan menghasilkan gabah hampa atau gabah setengah isi (Suparyono, 2007).

Upaya pengendalian terhadap penyakit $R$. solani pada padi selama ini dilakukan dengan menggunakan fungisida. Tindakan lainya adalah dengan menghilangkan faktor yang dapat mendukung perkembangan penyakit, misalnya dengan membersihkan sisa-sisa hasil panen tanaman padi dan gulma (Susilo et al., 2004). Pilihan terhadap penggunaan fungisida dianggap telah baik dan tepat, padahal dilihat dari segi efektivitas dan efesiensi pengendalian dengan menggunakan fungisida berspektrum luas akan semakin mendorong perkembangan OPT dan menimbulkan dampak negatif lain seperti resistensi dan resurgensi OPT. Penggunaan fungisida dalam ekosistem pertanian telah mengakibatkan berbagai kerusakan dan pencemaran lingkungan yang berdampak pada musnahnya keanekaragaman musuh alami dalam ekosistem, sehingga dengan adanya dampak yang terjadi, perlu adanya pembatasan atau penggunaan fungisida (Adriyani, 2006) untuk menghindari kerugian akibat penggunaan pestisida sintetik, pengendalian penyakit sebaiknya dilakukan secara terpadu.

Pengendalian secara terpadu diantaranya melalui pengembangan teknik pengendalian secara organik salah satunya penggunaan kitosan, yang berasal dari limbah cangkang kulit udang dapat digunakan sebagai alternatif pengendalian peyakit hawar pelepah. Pengendalian penyakit tanaman menggunakan kitosan dapat dilakukan karena kitosan mempunyai sifat anti mikroba. Kitosan memiliki gugus fungsional amina $\left(-\mathrm{NH}_{2}\right)$ bermuatan positif sangat kuat sehingga dapat menarik molekul asam amino bermuatan negatif pembentuk protein dalam mikroba. Muatan positif dan negatif ini berinteraksi secara elektrostatika yang menyebabkan membran mengalami tekanan permiabel sehingga tekanan osmotik di dalam sel tidak seimbang yang menghalangi pertumbuhan dari mikroba (Sarwono, 2010).

Hasil penelitian kitosan di Indonesia juga telah banyak dipublikasikan. Mawaddah et al. (2014) menyatakan bahwa kombinasi kitosan dan Trichoderma sp efektif menghambat pertumbuhan koloni cendawan Colletotrichum gloeosporioides secara in vitro. Hasil penelitian Fairuzah \& Daslin (2011) menunjukkan bahwa kitosan dapat mengendalikan rayap pada tanaman karet dengan cara pengumpanan dengan persentase mortalitas mencapai 54,8\% setelah 4 hari aplikasi. Damayanti et al. (2013) menyatakan perlakuan kitosan dapat mengganggu atau merusak asam nukleat Virus Bean Common Mosaic Virus (BCMV) pada kacang panjang. Selain itu, pemberian kitosan mampu menghambat luas koloni patogen Colletotrichum musae hingga 81,20\% pada buah pisang (Pamekas et al., 2009). Penelitian terkait pemanfaatan kitosan untuk mengendalikan penyakit pada tanaman secara in vitro telah banyak dilakukan. Uji antagonis kitosan terhadap cendawan Curvularia. sp dengan konsentrasi $1 \%, 1,5 \%$ dan 2 $\%$ mampu menghambat perkembangan miselium sebesar $51 \%$ (Husna, 2018 )

Penelitian terkait pemanfaatan kitosan untuk mengendalikan penyakit pada tanaman padi secara invitro telah banyak dilakukan. Uji antagonis kitosan terhadap cendawan Fusarium moniliforme yang merupakan penyakit pada benih tanaman padi Inpari 32, menunjukkan kitosan mampu menekan tingkat infeksi $F$. moniliforme sebesar $32.7 \%$ setelah benih disimpan selama dua minggu (Sakinah, 2018). Penelitian ini bertujuan untuk menguji keefektifan kitosan dalam menghambat pertumbuhan koloni $R$. solani dan menekan perkembangan penyakit hawar pelepah pada tanaman padi.

\section{BAHAN DAN METODE PENELITIAN}

Penelitian ini dilaksanakan di Balai Besar

Peramalan Organisme Penganggu Tanaman (BBPOPT) Jatisari Karawang, Jawa Barat. Uji pendahuluan dilaksanakan di Laboratorium Fitopatologi BBPOPT secara in vitro dengan menggunakan berbagai konsentrasi kitosan. Kitosan yang digunakan dalam pengujian merupakan hasil ekstraksi yang dilakukan oleh CV Bio Chitosan Indonesia di Kabupaten Cirebon. Pengujian kitosan dilakukan dengan metode feeding yaitu dengan cara membuat larutan kitosan yang dicampurkan pada media PDA sampai homogen. Miselium $R$. solani 
diambil dengan menggunakan cork borrer berdiameter $5 \mathrm{~mm}$ dan diletakkan di bagian tengah cawan petri. Sebagai kontrol $R$. solani ditumbuhkan pada media PDA tanpa pemberian kitosan.

Pengamatan dilakukan dengan meggunakan rumus metode El Ghaouth et al. (1992) yaitu dengan mengukur perkembangan luas miselium dan perkembangan sklerotia $R$. solani pada setiap perlakuan di mulai pada umur 2 HSI sampai miselium dan sklerotia tumbuh di permukaan cawan Petri. Adapun rumus perhitunganya sebagai berikut :

$$
\mathrm{P}=\frac{\mathrm{D} 1-\mathrm{D} 2}{\mathrm{D} 1} 100 \% \quad \mathrm{P}=\frac{\mathrm{D} 1-\mathrm{D} 1}{\mathrm{D} 1} 100 \%
$$

Keterangan:

$\mathrm{P}=$ Presentase penghambatan

$\mathrm{D} 1=$ Diameter cendawan tanpa perlakuan $(\mathrm{cm})$;

D2= Diameter cendawan dengan perlakuan $(\mathrm{cm})$.
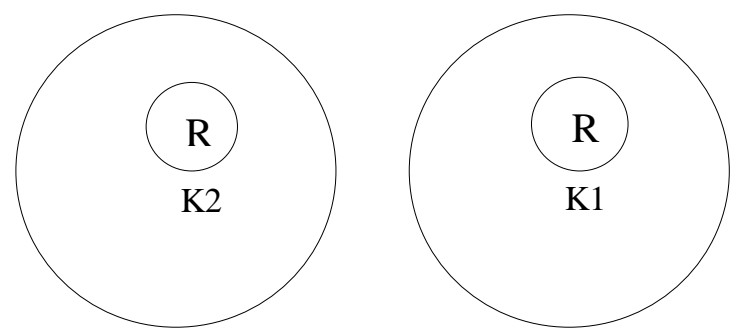

Gambar 1. Skema penempatan cendawan patogen dengan kitosan metode El Ghaouth .

$\mathrm{R}=$ cendawan $R$. solani $\mathrm{K} 1=$ Kontrol $\mathrm{K} 2=$ Patogen yang dihambat.

Penelitian utama dilaksanakan di lapangan pada tanaman padi varietas Ciherang dengan menggunakan Rancangan Acak Kelompok (RAK) yang terdiri dari 8 perlakuan dan 3 ulangan, sehingga terdapat 24 petak percobaan percobaan. Adapun ke delapan perlakuan tersebut yaitu:
A. Aplikasi kitosan dengan konsentrasi 0,5\%/100 $\mathrm{ml}$ asam asetat $1 \%$
B. Aplikasi kitosan dengan konsentrasi 1\%/100 ml asam asetat $1 \%$
C. Aplikasi kitosan. dengan konsentrasi 1,5\%/100 $\mathrm{ml}$ asam asetat $1 \%$
D. Aplikasi kitosan. dengan konsentrasi 2\%/100 ml asam asetat $1 \%$
E. Aplikasi kitosan. dengan konsentrasi 2,5\%/100 $\mathrm{ml}$ asam asetat $1 \%$
F. Aplikasi kitosan. dengan konsentrasi 3\%/100 ml asam asetat $1 \%$
G. Aplikasi kitosan. dengan konsentrasi 3,5\%/100 $\mathrm{ml}$ asam asetat $1 \%$
H. Tanpa Perlakuan (Kontrol)

Isolat $R$. solani yang digunakan diambil langsung dari tanaman padi yang menunjukkan gejala hawar pelepah di BBOPT Jatisari Karawang. Budi daya tanaman padi disesuaikan dengan cara petani setempat. Pengolahan tanah dilakukan dengan cara membajak tanah dua kali. Benih padi varietas
Ciherang yang diuji disemaikan terlebih dahulu dan dipindahkan ke lapangan pada umur 14 hari setelah sebar (HSS). Bibit tanaman diberi pupuk urea, dengan dosis $10 \mathrm{~kg} / \mathrm{ha}$. Selanjutnya bibit tanaman di pindahkan ke lapangan pada umur $21 \mathrm{HSS}$. Petak percobaan berukuran $3 \mathrm{~m}$ x $5 \mathrm{~m}$ dengan jarak tanam $25 \mathrm{~cm}$ x $25 \mathrm{~cm}$. Pemupukan dilakukan dua kali, pertama dengan Phonska pada saat tanaman berumur 0-10 HST (hari setelah tanam) dengan dosis $100 \mathrm{~kg} / \mathrm{ha}$ atau $150 \mathrm{~g} / \mathrm{plot}$. Pemupukan kedua pada 21-25 HST dengan dosis urea $300 \mathrm{~kg} / \mathrm{ha}$ atau $450 \mathrm{~g} / \mathrm{plot}$. Pengairan tanaman dilakukan dengan penggenangan terus-menerus setinggi $1-5 \mathrm{~cm}$. Pengendalian hama disesuaikan dengan kondisi pertanaman.

Perbanyakan inokulum $R$. solani dilakukan di Laboratorium BBOPT Jatisari Karawang. Pemurnian inokulum dengan cara pengambilan sampel tanaman yang memiliki pelepah sakit, dipotong 2-3 cm kemudian ditumbuhkan pada media PDA (Potato Dextrose Agar) selama 24 jam. Miselium jamur dipindahkan secara aseptis ke media PDA untuk digunakan sebagai biakan murni (Zuo et al., 2014 ) biakan murni diinkubasi selama 7 x 24 jam pada suhu ruangan $\left(25-30^{\circ} \mathrm{C}\right)$.

Waktu inokulasi inokulum $R$. solani yang berasal dari media PDA pada tanaman padi stadia anakan maksimum (30-35 HST), stadia bunting (4045 HST), stadia berbunga (50-60 HST), dan stadia pengisian malai (70-80 HST) (Rodrigues et al., 2003; IRRI, 2015; BBP Padi, 2018) Pada petak kontrol, tanaman tidak diberi inokulum $R$. solani. Inokulasi $R$. solani pada tanaman dilakukan dengan menyisipkan 5 $\mathrm{g}$ inokulum di sela-sela anakan padi dalam satu rumpun, kemudian diikat.

Pengamatan dilakukan dengan interval waktu satu minggu setelah inokulasi. Peubah yang diamati yaitu:

1. Keparahan penyakit hawar pelepah (Rhizoctonia solani) yang dilakukan pada umur tanaman 5 Minggu Setelah Tanam (MST), 6 MST, 7 MST dan 8 MST.

2. Hasil panen meliputi berat total bulir, berat bulir bernas, berat bulir hampa dan jumlah anakan.

3. Intensitas serangan penyakit diamati setelah dilakukan aplikasi dan diamati setiap 1 minggu. Penghitungan intensitas serangan penyakit hawar pelepah ( $R$. solani) menggunakan rumus berikut:

$$
\mathrm{IP}=\frac{\sum(n . v)}{N . V} \times 100 \%
$$

Keterangan:

IP = intensitas penyakit

$\mathrm{n}=$ jumlah tanaman yang menunjukkan gejala dengan kategori tertentu

$\mathrm{v}=$ nilai skala dengan kategori gejala tertentu

$\mathrm{N}=$ Jumlah tanaman sampel

$\mathrm{V}=$ Nilai skala tertinggi kategori gejala

Nilai kategori serangan (v) didasarkan pada luas serangan sebagai berikut (Mulyaningsih et al., 2005)

$0 \quad=$ Tidak ada kerusakan sama sekali (sehat) 
$1=$ Luas kerusakan $>0 \leq 25 \%$

$3=$ Luas kerusakan $>26 \leq 50 \%$

$5=$ Luas kerusakan $>51 \leq 75 \%$

$7=$ Luas kerusakan $>76 \leq 100 \%$

\section{HASIL DAN PEMBAHASAN}

Hasil Uji Pendahuluan yang dilaksanakan secara in vitro di laboratorium dengan berbagai macam konsentrasi kitosan menunjukkan bahwa

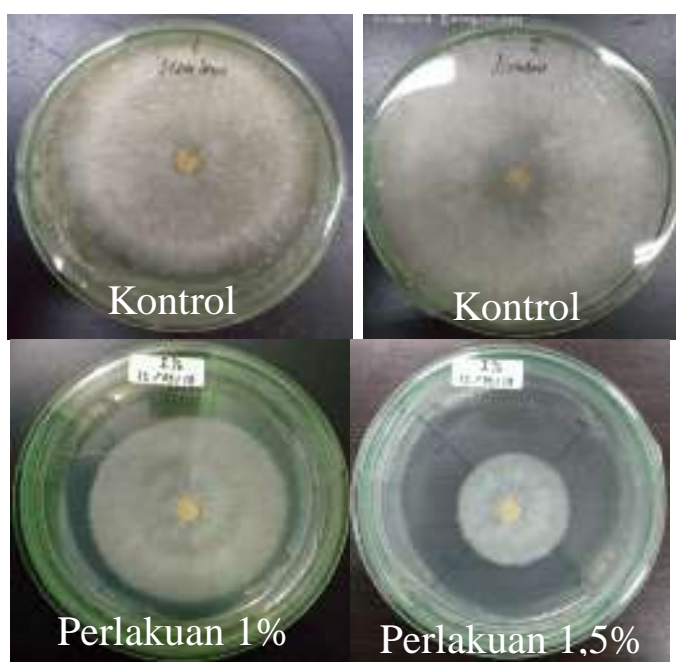

Perlakuan $1 \%$

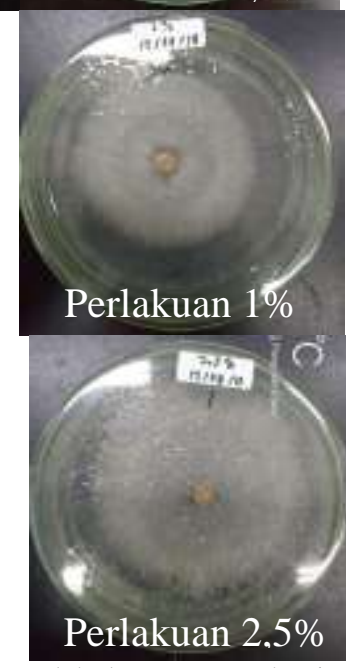

kitosan mampu menekan pertumbuhan miselium dan pembentukan sklerotia $R$. solani terutama pada konsentrasi 1,5\% (Gambar 2). Kemampuan kitosan di dalam menghambat pertumbuhan pathogen karena kitosan memiliki gugus fungsional amina $\left(\mathrm{NH}_{2}\right)$ dan kitosan mempunyai muatan positif, sedangkan sel membran mikroba bermuatan negatif. Muatan positif dan negatif ini berinteraksi yang menyebabkan matinya sel patogen (Sarwono, 2010).

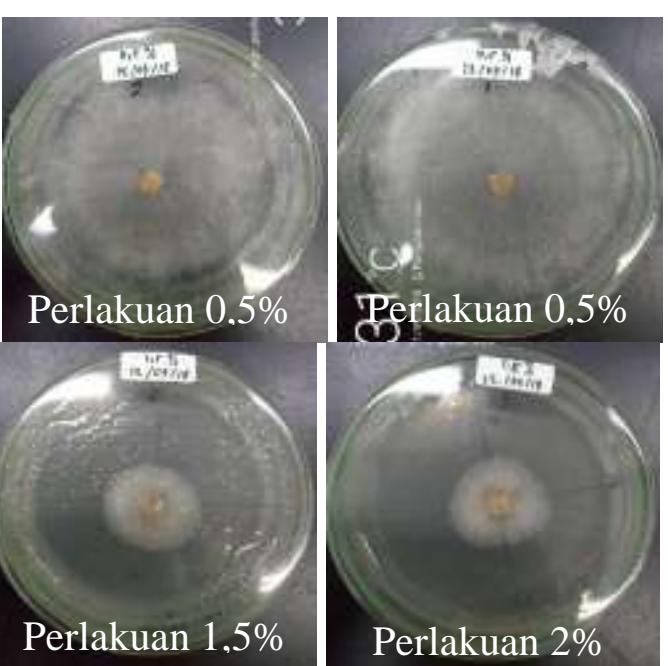

Gambar 2. Hasil Uji Pendahuluan Pengaruh Kitosan Terhadap Perkembangan miselium R. solani
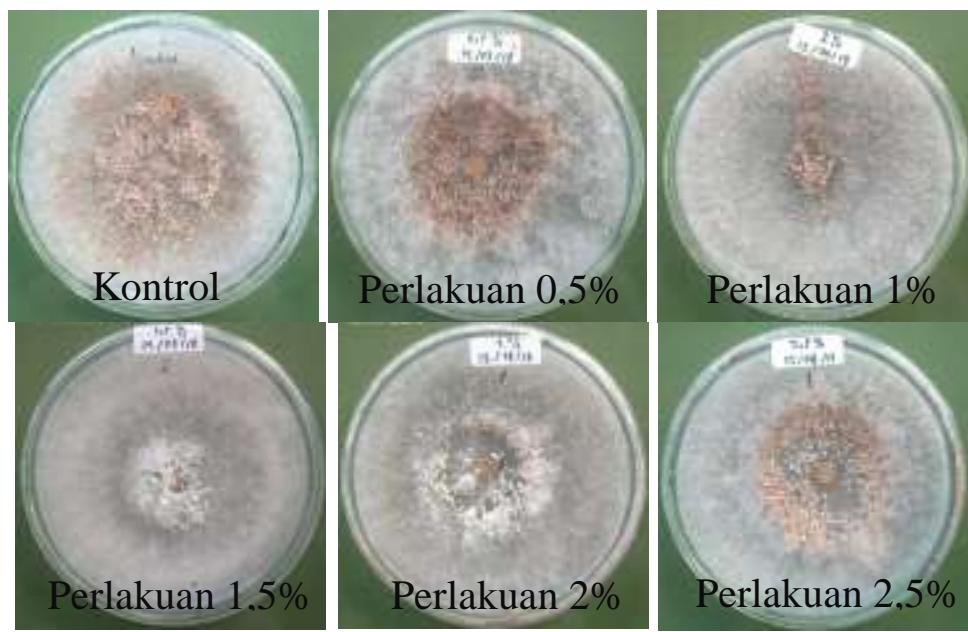

Gambar 3. Hasil Uji Pendahuluan Pengaruh Kitosan Terhadap perkembangan sklerotia R. solani 
Pengujian pendahuluan secara in vitro, terhadap perkembangan miselium $R$. solani dilakukan pada suhu $28^{\circ} \mathrm{C}$ selama 7 hari. Hal ini sesuai dengan kondisi suhu optimum pertumbuhan $R$. solani yaitu 25 - $32^{\circ} \mathrm{C}$. Selama masa inkubasi, pertumbuhan miselium diamati dengan mengukur diameter miselium dan sklerotia yang memenuhi cawan Petri. Persentase penghambatan pada masing-masing perlakuan disajikan pada Tabel 1.

Tabel 1 Pengaruh kitosan terhadap pertumbuhan miselium dan pembentukan sklerotia cendawan R. solani secara in vitro

\begin{tabular}{lcc}
\hline \multirow{2}{*}{ Konsentrasi Kitosan } & \multicolumn{2}{c}{ Penekanan perkembangan Rhizoctonia solani } \\
\cline { 2 - 3 } H (Kontrol) & Pertumbuhan miselium (\%) & Pembentukan sklerotia ( \%) \\
A $(0,5 \%)$ & 100,0 & 100,0 \\
B $(1 \%)$ & 78,26 & 58,74 \\
C $(1,5 \%)$ & 33,15 & 28,67 \\
D $(2 \%)$ & 22,27 & 18,87 \\
E $(2,5 \%)$ & 57,90 & 33,7 \\
\hline
\end{tabular}

Berdasarkan data pada (Tabel 1) semua konsentrasi kitosan yang di uji berpengaruh dalam menghambat pertumbuhan patogen $R$. solani. Hal ini ditunjukkan dari rata-rata diameter koloni $R$. solani setiap perlakuan yang lebih kecil dibandingkan terhadap kontrol. Penghambatan pertumbuhan miselium dan pembentukan sklerotia cendawan $R$. solani yang tertinggi dibandingkan dengan kontrol yaitu pada konsentrasi $1,5 \%$. Persentase perkembangan miselium pada konsentrasi 1,5\% adalah $22-27 \%$ sehingga pada perlakuan tersebut dapat menghambat perkembangan miselium sebesar $77,73 \%$.

Demikian juga dengan perkembangan sklerotia perlakuan kitosan $1,5 \%$ mempunyai persentase penghambatan sklerotia sebesar $81,13 \%$. Hal ini sesuai dengan hasil penelitian Hamdayanty et al. (2012) bahwa perlakuan kitosan secara umum mampu menekan infeksi cendawan patogen secara in vitro dengan tingkatan hambatan relatif yang semakin meningkat seiring dengan meningkatnya konsentrasi kitosan yang digunakan. Salah satu contohnya adalah reaksinya terhadap patogen Colletotrichum gloeosporioides yang mampu terhambat perkembangannya sebesar $72,17 \%$.

Hasil pengujian kitosan terhadap cendawan $R$. solani dalam skala laboratorium menghasilkan efek hambat yang cukup baik. Oleh karena itu, perlu adanya penelitian lanjutan mengenai keefektifan kitosan terhadap patogen $R$. solani di lapangan dengan berbagai konsentrasi kitosan. Hasil pengujian kitosan di lapangan terhadap intensitas serangan penyakit hawar pelepah pada tanaman padi dilakukan dengan frekuensi 7hari sekali sejak tanaman berumur 34 HST sampai menjelang panen. Kemunculan gejala pada pengamatan pertama yaitu saat tanaman berumur 34 HST tidak berbeda nyata untuk konsentrasi $0,5 \%$ dan
1\% terhadap kontrol. Hal serupa terjadi sampai pengamatan ke-2 saat umur tanaman 41 HST sedangkan pengamatan 48 HST konsentrasi 0, 5\% dan $2 \%$ tidak berbeda nyata dengan kontrol. Pengaruh kitosan mulai terlihat pada saat tanaman berumur 55 HST. Hal ini terlihat dari persentase perkembangan penyakit pada konsentrasi kitosan yang terendah $0,5 \%$ berbeda nyata terhadap control (Tabel 2).

Proses penghambatan masih terus berjalan, terbukti pada pengamatan terakhir yaitu pada saat tanaman menjelang panen peran kitosan cukup berpengaruh terhadap perkembangan penyakit hawar pelepah. Perlakuan yang mampu menghambat paling tinggi yaitu perlakuan dengan konsentrasi 1,5\% yang ditunjukan dengan gejala infeksi, dengan intensitas serangan sebesar 9,67\%. Semakin tinggi konsentrasi kitosan yang diaplikasikan tidak menghasilkan penghambatan yang semakin tinggi juga pada penelitian ini. Berdasarkan hasil pengamatan, konsentrasi yang tinggi memberikan penekanan pathogen yang lebih rendah dibandingkan dengan konsentrasi yang lebih rendah (Tabel 2).

Hal ini diduga disebabkan oleh kemampuan kitosan dalam membunuh mikroba yang bergantung pada beberapa faktor, tidak hanya pada konsentrasi saja seperti tingkat destilasi serta karakteristik dan ketahanan mikroba (Goy et al., 2009). Pada penelitian ini, faktor lingkungan diduga mempengaruhi serangan $R$. solani yang terlihat pada pengamatan 41 HST yang mengalami peningkatan serangan $R$. solani dan pada pengamatan 48 HST mengalami penurunan hingga pengamatan terakhir 55 HST mengalami peningkatan. Demikian juga diperkirakan varietas rentan yang digunakan pada penelitian ini telah mendukung kejadian penyakit hawar pelepah pada tanaman padi. 
Tabel 2. Pengaruh konsentrasi kitosan terhadap perkembangan penyakit hawar pelepah di lapangan

\begin{tabular}{lllll}
\hline \multirow{2}{*}{ Perlakuan } & \multicolumn{4}{c}{ Intensitas serangan penyakit Hawar pelepah (\%) } \\
\cline { 2 - 5 } & $34 \mathrm{HST}$ & $41 \mathrm{HST}$ & $48 \mathrm{HST}$ & $55 \mathrm{HST}$ \\
\hline H (Kontrol) & $8,87 \mathrm{a}$ & $18,41 \mathrm{a}$ & $16,10 \mathrm{a}$ & $31,80 \mathrm{a}$ \\
A $(0,5 \%)$ & $8,28 \mathrm{a}$ & $16,79 \mathrm{ab}$ & $13,25 \mathrm{ab}$ & $23,83 \mathrm{~b}$ \\
B $(1 \%)$ & $8,06 \mathrm{a}$ & $12,65 \mathrm{abc}$ & $10,02 \mathrm{bc}$ & $15,68 \mathrm{~cd}$ \\
C $(1,5 \%)$ & $4,17 \mathrm{~b}$ & $7,89 \mathrm{c}$ & $7,69 \mathrm{c}$ & $9,67 \mathrm{~d}$ \\
D $(2 \%)$ & $5,73 \mathrm{ab}$ & $10,66 \mathrm{bc}$ & $10,60 \mathrm{abc}$ & $13,86 \mathrm{~cd}$ \\
E $(2,5 \%)$ & $7,05 \mathrm{ab}$ & $10,96 \mathrm{bc}$ & $10,35 \mathrm{bc}$ & $16,74 \mathrm{bc}$ \\
F $(3 \%)$ & $4,03 \mathrm{~b}$ & $7,70 \mathrm{c}$ & $7,26 \mathrm{c}$ & $13,04 \mathrm{~cd}$ \\
G $(3,5 \%)$ & $4,33 \mathrm{~b}$ & $7,59 \mathrm{c}$ & $7,69 \mathrm{c}$ & $11,43 \mathrm{~cd}$
\end{tabular}

Keterangan: Angka yang di ikuti oleh huruf yang sama pada kolom yang sama pada masing-masing faktor menunjukan tidak berbeda nyata berdasarkan uji jarak berganda Duncan pada taraf $5 \%$. HST = Hari Setelah Tanam. HST: hari setelah tanam.

Hasil penelitian menunjukkan bahwa dengan bertambahnya umur tanaman, intensitas serangan hawar pelepah mengalami peningkatan. Pelakuan yang paling baik dalam menekan intensitas serangan hawar pelepah adalah perlakuan dengan konsentasri $1,5 \%$. Hal ini terjadi karena senyawa kitin dalam struktur dinding sel miselium cendawan patogen bermuatan negatif sedangkan dalam kitosan yang bermuatan positif dapat berikatan dengan bagian makromolekul yang bermuatan negatif pada permukaan sel patogen. Hal inilah yang menyebabkan pertumbuhan jamur menjadi terhambat sehingga mengakibatkan infeksi lambat berkembang.

Semua perlakuan kitosan belum terlihat pengaruhnya pada minggu pertama pengamatan. Laju perkembangan penyakit pada perlakuan kitosan konsentrasi $0,5 \%$ sangat cepat, sebanding dengan kontrol (tanpa aplikasi kitosan). Perlakuan dengan konsentrasi $1 \%$ mengalami kenaikan intensitas penyakit pada pengamatan kedua dan pengamatan terakhir walaupun sempat turun lajunya pada saat pengamatan ketiga. Hal ini disebabkan respons tanaman untuk beradaptasi terhadap infeksi patogen. Konsentrasi kitosan $1 \%$ dan 1,5\% tidak menunjukkan peningkatan laju penyakit yang tinggi. Perlakuan dengan konsentrasi di atas 1,5\% sangat lambat namun intensitas penyakit lebih rendah dibandingkan dengan konsentrasi 3,5\%. Penambahan kitosan dapat menghambat pertumbuhan cendawan baik secara vegetatif maupun reproduktif (Rogis et al., 2007). Nurafida (2014) menyatakan bahwa pemberian kitosan akan menghambat pertumbuhan miselium dan perkecambahan spora cendawan patogen karena adanya akitivitas kitinase. Aktivitas kitinase dapat menghidrolisis berbagai bentuk kitin pada dinding sel yang dimanfaatkan mikoba sebagai sumber karbon.
Pengamatan jumlah anakan produktif pada tanaman padi Varietas Ciherang dilakukan pada saat tanaman menjelang panen. Pada Tabel 3 dijelaskan bahwa selain perlakuan konsentrasi $1,5 \%$ rata-rata jumlah anakan produktif berbeda nyata dengan kontrol. Hal ini sangat terbalik dari intensitas serangan yang terendah ditimbulkan oleh cendawan $R$. solani. Perbedaan konsentrasi kitosan dari masing masing perlakuan yang berpengaruh terhadap berat kandungan yang dimiliki dari kitosan itu sendiri. Hasil yang tak sama dari masing - masing perlakuan di sebabkan oleh banyak faktor baik lingkungan, kelembapan, suhu, kecepatan angin udara dan konsentrasi kitosan itu sendiri. Dilaporkan bahwa keefektifan kitosan tergantung pada konsentrasi yang di gunakan, jenis kitosan (murni atau turunan), derajat polimerasi, inang, komposisi subtrat, dan kondisi lingkungan. Aktivitas antimikroba juga meningkat seiring dengan peningkatan bobot molekul dari kitosan tersebut.

Berdasarkan hasil analisis, perlakuan dengan konsentrasi 3,5\% menghasilkan jumlah anakan yang paling tinggi dari semua perlakuan dan tidak berbeda nyata dengan perlakuan $1 \%, 2,5 \%$ dan $3 \%$. Keberhasilan kitosan dalam meningkatkan jumlah anakan produktif dikarenakan adanya hormon pertumbuhan yang dikeluarkan oleh kitosan terhadap tanaman. Kitosan dapat meningkatkan aktifitas hormon auksin melalui jalur independen triptofan (Uthairatanakij et al., 2007).

Pengamatan berat total bulir pada tanaman padi varietas Ciherang dilakukan pada tanaman padi menjelang panen. Berat bulir padi diperoleh dengan cara menimbang seluruh berat hampa maupun bernas. Berdasarkan data pada Tabel 4, perlakuan konsentrasi 3,5\% menghasilkan berat bulir total paling tinggi. 
Pengaruh kitosan mampu meningkatkan produksi bulir lebih baik dibandingkan kontrol. Perannya sebagai pemacu pertumbuhan terbukti dengan produksi hasil panen yang tinggi. Demikian juga peran lainnya yaitu sebagai bahan pengendali patogen dapat didukung dari hasil analisis bulir hampa yang dihasilkannya.

Tabel 3. Pengaruh perlakuan konsentrasi kitosan terhadap jumlah anakan produktif padi

Konsentrasi kitosan Anakan Produktif (Rumpun)

$(\%)$

\begin{tabular}{lc}
\hline H (Kontrol) & $11,67 \mathrm{ab}$ \\
A $(0,5 \%)$ & $10,51 \mathrm{bc}$ \\
B $(1 \%)$ & $11,87 \mathrm{a}$ \\
C $(1,5 \%)$ & $10,48 \mathrm{c}$ \\
D $(2 \%)$ & $10,00 \mathrm{c}$ \\
E $(2,5 \%)$ & $11,74 \mathrm{a}$ \\
F $(3 \%)$ & $10,75 \mathrm{abc}$ \\
G $(3,5 \%)$ & $11,92 \mathrm{a}$
\end{tabular}

Keterangan: Angka yang di ikuti oleh huruf yang sama pada kolom yang sama pada masing-masing faktor menunjukan tidak berbeda nyata berdasarkan uji jarak berganda Duncan pada taraf 5\%. HST = Hari Setelah Tanam.

Tabel 4. Pengaruh perlakuan konsentrasi kitosan terhadap berat total bulir padi per rumpun

\begin{tabular}{lcll}
\hline $\begin{array}{l}\text { Konsentrasi } \\
\text { kitosan }(\%)\end{array}$ & $\begin{array}{c}\text { Berat Bulir } \\
\text { Padi }(\mathrm{g})\end{array}$ & $\begin{array}{l}\text { Berat Bulir } \\
\text { Hampa }(\mathrm{g})\end{array}$ & $\begin{array}{l}\text { Berat Bulir } \\
\text { Bernas }(\mathrm{g})\end{array}$ \\
\hline H (Kontrol) & $1,87 \mathrm{ab}$ & $0.282 \mathrm{a}$ & $1.36 \mathrm{c}$ \\
A $(0,5 \%)$ & $1,56 \mathrm{~cd}$ & $0.195 \mathrm{~b}$ & $1.37 \mathrm{c}$ \\
B (1\%) & $1,68 \mathrm{bcd}$ & $0.177 \mathrm{~b}$ & $1.44 \mathrm{bc}$ \\
C (1,5\%) & $1,53 \mathrm{~d}$ & $0.173 \mathrm{bc}$ & $1.36 \mathrm{c}$ \\
D (2\%) & $1,67 \mathrm{bcd}$ & $0.175 \mathrm{bc}$ & $1.58 \mathrm{abc}$ \\
E (2,5\%) & $1,79 \mathrm{abc}$ & $0.154 \mathrm{bc}$ & $1.63 \mathrm{ab}$ \\
F (3\%) & $1,84 \mathrm{ab}$ & $0.150 \mathrm{bc}$ & $1.69 \mathrm{ab}$ \\
G $(3,5 \%)$ & $1,98 \mathrm{a}$ & $0.129 \mathrm{c}$ & $1.72 \mathrm{a}$
\end{tabular}

Keterangan: Angka yang di ikuti oleh huruf yang sama pada kolom yang sama pada masing-masing faktor menunjukan tidak berbeda nyata berdasarkan uji jarak berganda Duncan pada taraf 5\%. HST = Hari Setelah Tanam

Berdasarkan hasil analisis, semua perlakuan kitosan tidak berbeda nyata dengan kontrol. Namun, secara rata-rata perlakuan kitosan dengan konsentrasi 3, 5\% mampu menghasilkan produksi bulir yang paling banyak. Hal tersebut memperlihatkan bahwa adanya perbedaan keefektifan kerja bagi masingmasing konsentrasi kitosan dalam hal meningkatkan komponen pertumbuhan dan hasil. Hal ini sejalan dengan pendapat Winarno ( 2015 ) yang mengungkapkan bahwa maafaat kitosan antara lain dapat mempercepat pertumbuhan akar, sehingga pertumbuhan tanaman menjadi lebih baik, selain itu kitosan berfungsi untuk memperbaiki tanah yang sudah rusak serta dapat meningkatkan hasil produksi tanaman.
Pengaruh kitosan terhadap patogen dapat juga terlihat dari berat bulir hampa yang dihasilkannya. Cendawan $R$. solani menginfeksi tanaman dengan menginvasi jaringan tanaman sehingga menyebabkan penyerapan nutrisi dan penyebaran hasil fotosintesis menjadi terganggu. Hal ini dapat menyebabkan terganggunya proses pengisian bulir. Bulir yang tidak terisi sempurna akan mengakibatkan berat menjadi lebih ringan dibandingkan dengan bulir yang sehat. Tabel 4. Menggambarkan bahwa berat bulir hampa pada perlakuan kitosan 3, $5 \%$ memiliki berat hampa yang paling rendah dan berat bulir bernas paling tinggi diantara perlakuan lainnya. Hasil ini tidak berlaku pada perlakuan $1,5 \%$ yang menunjukkan intensitas 
penyakit pada saat pengamatan paling rendah. Hal ini dikarenakan perbedaan konsentrasi pada perlakuan kitosan memiliki jumlah berat yang berbeda-beda yang menyebabkan perbedaan pengaruh terhadap hasil produksi. Dalam kosentrasi tertentu kitosan hanya mampu menekan intensitas serangan cendawan patogen, tetapi tidak untuk meningkatkan produksi tanaman padi dan untuk meningkatkan produksi dengan konsetrasi yang maksimal dapat meningkatkan produktivitas suatu tanaman. Hal ini sejalan Uthairatanakij et al. (2007) yang mengungkapkan bahwa dalam meningkatkan produksi tanaman keberhasilan kitosan memberikan pengaruh berbeda tergantung konsentrasi terhadap tanaman terutama menstimulir hormon pertumbuhan. Karena kitosan merangsang proses dekomposisi bahan organik dalam meningkatkan fungsi nitrogen di dalam tanah dan meningkatkan fikasi $\mathrm{CO}_{2}$ dan produksi $\mathrm{O}_{2}$ akibat dari penambahan kitosan (Chibu \& Hidejiro, 1999) peningkatan konsentrasi kitosan memberikan pengaruh positif terhadap fisiologi tanaman (Uthairatanakij et al., 2007).

Berdasarkan hasil analisis semua konsentrasi berpengaruh terhadap berat bulir hampa (Tabel 4.) Perlakuan dengan konsentrasi 3,5\% memiliki berat bulir hampa yang paling sedikit dibanding kontrol. Hal ini dikarenakan pengaruh kitosan berpotensi dapat mengurangi munculnya gabah hampa akibat serangan $R$. solani. Hasil ini didukung dengan hasil perhitungan berat bulir bernas yang berbeda nyata dengan kontrol yaitu seberat 1,72 gram

Penyakit hawar pelepah terhadap tanaman padi dapat mengakibatkan terganggunya proses pertumbuhan dan mengakibatkan tanaman tumbuh tidak normal, hasil padi dan kualitas gabah menurun. Serangan yang terjadi pada pelepah padi hingga ke malai karena infeksi cendawan patogen mengakibatkan dalam pengisian proses bulir menjadi tidak sempurna dan kurang optimal. Hal ini sejalan dengan pendapat Inagaki (2001) bahwa cendawan $R$. solani berkecambah dan menginfeksi bagian pelepah daun padi, kemudian berkembang ke arah dalam dan menginfeksi bagian batang padi. Lebih lanjut dikemukakan bahwa kerusakan yang terjadi pada ruas batang menyebabkan tanaman padi mudah rebah serta dapat menghambat aliran air dan nutrisi. Perkembangan lebih lanjut, infeksi dapat mencapai seluruh bagian daun dan menimbulkan gejala hawar yang dapat meluas sampai ke daun bendera dan kerebahan yang terjadi saat tanaman padi berada pada stadium pengisian malai, mengakibatkan pengisian tidak sempurna dan banyak terbentuk gabah hampa (Nuryanto et al., 2011).

\section{KESIMPULAN DAN SARAN}

\section{Kesimpulan}

Berdasarkan pembahasan hasil penelitian, maka dapat diperoleh kesimpulan sebagai berikut :
1. Secara in vitro perlakuan kitosan dengan konsentrasi $1,5 \%$ dapat menghambat pertumbuhan miselium sebesar $77,73 \%$ dan persentase penghambatan sklerotia $R$. solani sebesar 81,13\% sedangkan di lapangan dapat menghambat perkembangan intensitas serangan R. solani sebesar $9,67 \%$.

2. Perlakuan kitosan dengan konsentrasi 1, 5\% efektif menghambat perkembangan penyakit hawar pelepah $R$. solani dan pada konsentrasi 3,5 $\%$ dapat meningkatkan berat bulir padi.

\section{Saran}

Berdasarkan hasil pengamatan dan pembahasan, untuk melihat efektifitas kitosan dalam mengendalikan $R$ solani dengan konsentrasi yang terbaik, perlu dilakukan penelitian lanjutan dengan menggunakan kitosan pada tanaman padi yang telah terinfeksi $R$. solani di lokasi yang lain pada lahan yang lebih luas.

\section{DAFTAR PUSTAKA}

Adriyani R. 2006. Usaha pengendalian pencemaran lingkungan akibat penggunaan pestisida pertanian. Jurnal Kesehatan Lingkungan. 3(1): 95-106.

Balai Besar Penelitian Tanaman Padi (BBP Padi). 2018. Beras ramping lebih disukai pasar. http://bbpadi.litbang.pertanian.go.id/index.ph p/berita/info aktual/content/ 552-berasramping-lebih-disukai-pasar [Diakses 20 September 2019].

Badan Pusat Statistik. 2018. Produksi Padi Tahun 2018. Tersedia online pada http://www.bps.go.id/brs/view/id/1122. Diakses pada tanggal 12 Februari 2019.

Chibu H, \& Hidejiro S. 1999. Effects of chitosan application on shoot growth of several crop seedlings. J. Hort Scie. 9 : 15-20.

Damayanti TA, Haryanto \& Wiyono S. 2013. Pemanfaatan kitosan untuk pengendalian Bean Common Mosaic Virus (BCMV) pada kacang panjang. J. HPT Tropika. 13(2): 110116.

Dinas Pertanian Tanaman Pangan Jawa Barat. 2018. Produksi Beras Indonesia Naik 3,6 $3 \%$ per Tahun. Dinas Tanaman Pangan dan Hortikultura Provinsi Jawa Barat. Tersedia online pada http://distan.jabarprov.go.id/distan/blog/detai 1/2104-produksi-beras-indonesia-naik-3-63per-tahun. Diakses 9 Maret 2020.

El Ghaouth A, Arul J, Grainer J, \& Asselin A. 1992. Antifungal Activity of chitosan on two postharvest pathogens on strawberry fruits. Phytophatology. 82: 398-402.

Fairuzah Z, \& Daslin A. 2011. Efektivitas toksisitas kitosan untuk mengendalikan rayap (Coptotermes curvignathu Holmgren) pada tanaman karet. Widyariset. 14(2): 439-446. 
Goy RC, Britto D, \& Assis OBG. 2009. A review of the antimicrobial activity of chitosan. Polimeros. 19(3): 241-247.

Guo Q, Kamio A, Sharma BS , Sagara Y, Arakawa M, \& Inagaki K. 2006. Survival and Subsequent Dispersal of Rice Sclerotial Disease Fungi, Rhizoctonia Oryzae and Rhizoctonia Oryzae-Sativae, in Paddy Fields Plant Dis. 90 (5): 615-622.

Hamdayanty R, Yunita, Amin N, \& Damayanti TA. 2012. Pemanfaatan kitosan untuk mengendalikan antraknosa pada pepaya (Colletotrichum gloeosporioides) dan meningkatkan daya simpan buah. Jurnal Fitopatologi Indonesia. 8(4): 97-102

Husna SF. 2018. Pengaruh Kitosan Terhadap Pertumbuhan Culvularia Sp. dan Botryodiplodia theobromae Pada Media Agar. Menara Perkebunan. 87(1), 41-51

Inagaki K. 2001. Outbreaks of rice sclerotium diseases in paddy fields and physioligical and ecological characteristics of this casual fungi. Science Replications Agricultures. 37: 57-66.

International Rice Research Institute (IRRI). 2015. Step to Successful Rice Production. IRRI. Los Banos. Philippines.

Mawaddah FS, Prasetyo J, \& Nurdin M. 2014. Pemanfaatan Kitosan dan Trichoderma Sp. Untuk Mengendalikan Penyakit Antraknosa (Colletotrichum Gloeosporioides Penz.) Pada Buah Pisang Cavendish. Jurnal Agrotek Tropika. 2(2): 215-219.

Mulyaningsih ES, Indrayani S, \& Slamet-Loedin IH. 2005. Analisis molekuler dan uji ketahanan tanaman padi transgenik yang mengandung gen kitinase generasi ke tiga(T2) terhadap Rhizoctonia solani Kuhn dan Pyricularia oryzae. Cav. Jurnal Biosfera. 22(3): 42151.

Nurafida D. 2014. Keefektifan Kitosan dalam Mengendalikan Botryodiplodia sp. pada Jabon (Anthocephalus cadamba) secara in Vitro. Departemen Silvikultur. Fakultas Kehutanan Institut Pertanian Bogor.

Nuryanto B, Priyatmojo A, Hadisutrisno B, \& Sunarminto BH. 2011. Perkembangan penyakit hawar upih padi (Rhizoctonia solani Kuhn) di sentra-sentra penghasil padi Jawa Tengah dan Daerah Istimewa Yogyakarta. Jurnal Budidaya Pertanian. 7(1): 1-7.
Nuryanto B. 2017. Penyakit hawar pelepah Rhizoctonia solani pada padi dan taktik pengelolaannya. Jurnal Perlindungan Tanaman Indonesia. 21(2): 63-71.

Pamekas T, Sumardiyono C, Pusposendjojo N \& Indradewa D. 2009. Ekstraksi, karakterisasi dan daya penghambatan kitosan alami terhadap jamur Colletrichum musae secara in vitro. Jurnal Perlindungan Tanaman Indonesia. 15(1): 39-44.

Rodrigues, F.A., F.X.R. Vale, L.E. Datnoff, A.S. Prhabu, and G.H.Kordofer. 2003. Effect of rice growth stage and silicon on sheath blight development. Phytopatology. 93(3): 256261.

Rogis A, Pamekas T, \& Mucharromah. 2007. Karakteristik dan uji efikasi bahan senyawa alami kitosan terhadap patogen pascapanen antraknosa Colletotrichum musae. J Ilmu Ilmu Pertanian Indonesia. 9(1): 58-63.

Sakinah NA. 2018. Aplikasi Ekstrak Adas dan Kitosan untuk Pengendalian Cendawan Patogen Terbawa Benih Padi (Oryza sativa L.). Departemen Proteksi Tanaman Fakultas Pertanian Institut Pertanian Bogor

Sarwono R. 2010. Pemanfaatan kitin/kitosan sebagai bahan anti mikroba. JKTI. 12(1): 32-38.

Soenartiningsih, Akil M, \& Andayani NN. 2015. Cendawan tular tanah (Rhizoctonia solani) penyebab penyakit busuk pelepah pada tanaman jagung dan sorgum dengan komponen pengendaliannya. Jurnal Iptek Tanaman Pangan. 10(2): 85-92.

Susilo PL, Soesanto \& Wachjadi M. 2004. Pengaruh penggunaan fungisida sintetis dan Trichoderma sp. secara tunggal atau gabungan terhadap penyakit hawar pelepah daun padi. Jurnal Pembangunan Pedesaan. 5(1): 34-41.

Uthairatanakij A, Silva JAT, \& Obsuwan K. 2007. Chitosan for improving orchid production and quality. Orchid Science and Biotechnology. 1(1): 1-5.

Winarno. 2015. Pengantar Teknologi Pangan . PT Gramedia . Jakarta

Zuo G, Li Q, Hao B. 2014. K-peptide length in composition vector phylogeny of prokaryotes. Computational Biology and Chemistry. 53: 166-173. DOI: 10.1016/j.compbiolchem.2014.08.021

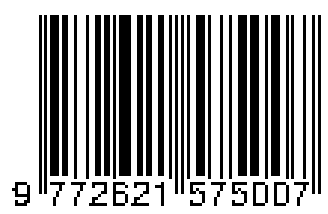

